Original Research Paper

\title{
The Contribution of Cibodas Botanic Garden as An Ex-situ Conservation Site for Tropical Mountainous Plants: The last decade
}

\author{
Imawan Wahyu Hidayat ${ }^{1 *}$, Neneng Ine Kurnita1, Dimas Ardiyanto ${ }^{1}$ \\ ${ }^{1}$ Cibodas Botanic Garden - Research Center for Plant Conservation and Botanic Garden, Indonesian Institute of Sciences
}

\author{
Article history \\ Received: August $13^{\text {th }}, 2019$ \\ Revised: August 28 ${ }^{\text {th }}, 2019$ \\ Accepted: September $4^{\text {th }}, 2019$ \\ Published : September $12^{\text {th }}, 2019$ \\ *Corresponding Author: \\ Imawan Wahyu Hidayat, \\ Cibodas Botanic Garden - \\ Research Center for Plant \\ Conservation and Botanic \\ Garden, Indonesian Institute of \\ Sciences; \\ Email: imaw001@lipi.go.id
}

\begin{abstract}
The threats to the plant biodiversity become more advance along with rapid degradation of the natural habitat. Plants preservation needs accompaniment between in-situ and ex-situ conservation altogether. The ex-situ plant conservation plays more important roles in order to help conserve threatened plant species. Cibodas Botanic Garden (CBG) is a government institution which has the main assignment on ex-situ plant conservation, especially tropical mountainous plants. In the last decade, $\mathrm{CBG}$ has conducted exploration and plants collection in order to retrieve them from the destructive pressures in their habitat. This study aimed to asses the CBG's contribution to ex-situ plant conservation through the addition number of planted plants and to describe the important value to conservation. The study conducted through a quantitative descriptive method, based on data inventory of the newly planted plant in the garden from 2008 to 2018. This also assessed the increasing collection of each year and descriptively explaining the background data, species variety, and their conservation status. The results described that the additional number was 473 specimens and the average increase was 43 specimens per-year. These originated from exploration and plants collection 248 specimens, donation 217 specimens, self-propagation seven specimens, and one specimen from seeds exchange. The most planted was Nepenthaceae with 84 specimens, secondly Phillantaceae with 21 specimens, and Lauraceae 15 specimens. There were 116 species (152 specimens) which have conservation status. These expected to be a comprehensive description of the CBG's plant collection and meaningful for the conservation efforts in general.
\end{abstract}

Keywords: $e x$-situ plant conservation; garden collection; Cibodas Botanic Garden (CBG)

\section{Introduction}

The conservation in plants is greatly underresourced in examination with the conservation of animals (Havens et al., 2014). The plants conservation diversity has received considerably less interest than the animals conservation, perhaps because plants lack the favorite attract of many animal groups (Goettsch et al., 2015). Furthermore, the existence of wild plants in their ecosystem getting pressed. The extant habitats of a growing number of species are becoming less viable for their survival for a variety of reasons, including global warming, disease, drought, fragmentation, and deforestation (Braverman, 2014).

For example, thirty-eight percent of remaining forest of Sumatran tropical rainforest in 2007 was "critically endangered", "endangered" or "vulnerable" eco-floristic sectors (five million ha) but only one million ha $(20 \%)$ were protected (Laumonier et al., 2010). It has also occurred in mountains forest since
1985-2007, in totally, $41 \%$ forest loss has occurred in South, Central and North Sumatra. Within extraordinary pressures to the existence of conservation areas, it should be carried out immediately noticeable efforts in conservation sectors.

Various efforts need to be made to minimize the threat caused by the continued reduction of tropical forests, one of which is to exert ex-situ conservation efforts. In order to maintain many species, an alternative habitat (or the existing one) might be (re) constructed and managed (Braverman, 2014). Moreover, ex-situ plant collections would help conserve threatened species (Richards et al., 2007), function as a source of traits for agricultural improvement (Tanksley \& Mccouch, 1997; Brummer et al., 2011; Neale \& Kremer, 2011), or has been used to propagate large numbers of individual plant for ecosystem restoration or assisted migration (Broadhurst et al., 2008; Vitt et al., 2010; Aitken \& Whitlock, 2013). 
Cibodas Botanic Garden (CBG) based on the Decree of the Chairman of Indonesian Institute of Sciences (LIPI) January 17, 1987, No.23/KEP/ D.5./87, CBG has the task to conduct exploration and plant conservation of tropical wet highlands. CBG has an important role to conduct exploration and research activities of tropical wet highlands plants. In the last decade, CBG has conducted of exploration and plants collection at Sumatran mountains. These collected plants were those species which threatened, has no collection in the garden or has a potential usefulness. Plants which collected from their natural habitat will be maintained and planted in the garden, ex-situ conservation, which will enrich plants collection of CBG. Before a plant becomes a collection of $\mathrm{CBG}$, it must go through a series of data processing in order to insure the plant data.

The objectives of the study were to assess the CBG's contribution to $e x$-situ plant conservation through the addition number of planted plants from 2008 to 2018 and to describe the important value of these plants to conservation. The results were expected to be a comprehensive description of the CBG's plant collection, as an effort on ex-situ plant conservation, and also meaningful for the conservation efforts in general.

\section{Materials and Methods}

The study was conducted at CBG, Cianjur, West Java. CBG is located at $107^{\circ} 0^{\prime} 10.476^{\prime \prime} \mathrm{E}$ to $107^{\circ} 0^{\prime}$ $59.275^{\prime \prime} \mathrm{E}$ and $6^{\circ} 44^{\prime} 6.787^{\prime \prime} \mathrm{S}$ to $6^{\circ} 44^{\prime} 51.112^{\prime \prime} \mathrm{S}$ (Figure 1). The location is mountainside of mount Gede and mount Pangrango, at an altitude of approximately 1,300-1,425 meters above sea level, with an area of 84.99 hectares (Widyatmoko et al., 2010). The average temperature is $20{ }^{\circ} \mathrm{C}$, humidity of $80.82 \%$ and an average rainfall of $2,950 \mathrm{~mm}$ per year (Registration UnitCBG, 2018a). CBG is ex-situ plants conservation with various types of plants that mostly originated from Indonesia, more than 60\% (Registration Unit-CBG, 2018b), especially from tropical wet highland, and other foreign countries.

In this study, plants collection enrichment was only assessed from three sources of plants acceptance: (1) exploration, (2) donation, (3) self-propagation effort by CBG staff, and (4) seeds exchange (if any). Plant seeds exchange is one of the botanic gardens business in order to develop the conservation value of the garden (Davis, 2008; BGCI, 2012). Nonetheless, along with the increasingly strict regulations in Indonesia (such as Peraturan Pemerintah Republik Indonesia Nomor 7 Tahun 1999 and Peraturan Menteri Lingkungan Hidup dan Kehutanan Republik Indonesia Nomor P.106/MENLHK/SETJEN/ KUM.1/12/2018), then this effort is restricted by CBG.

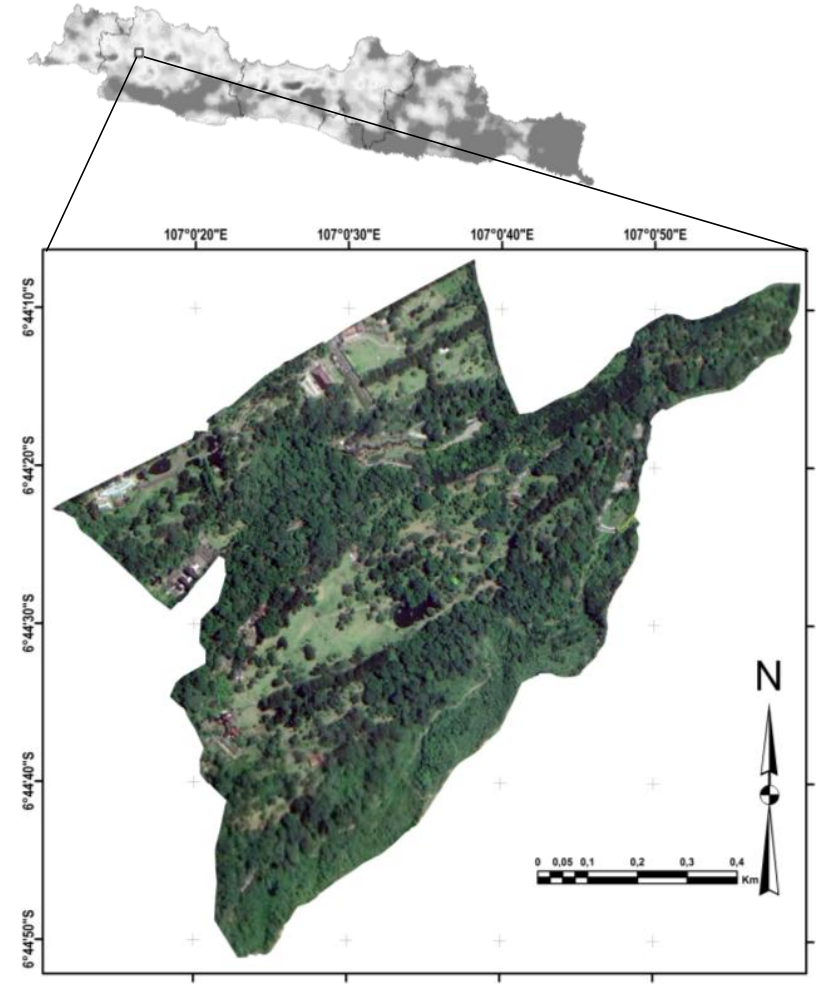

Figure 1. Study area at Cibodas Botanic Garden.

A plant can be referred to as enrichment of garden collection if it has been through a series of the registration process and finally determined as the addition of garden collection. The number of plants enrichment was assessed from 2008 to 2018. In each year, will be analyzed the number of enrichment, the sources of acceptance and plants species were dominated planted in the garden. Then, statistically will be analyzed the addition of each year. The trend of adding number of the collections was done through a simple regression analysis by formula: $y_{i}=a+b x_{i}$.

Moreover, it will be explained plants species which have a high conservation value, such as a threatened or vulnerable, etc., based on International Union for the Conservation of Nature (IUCN) status and/or has no collection in the garden. This is expected to give an explanation of CBG contribution efforts in exsitu plants conservation, and for further research and education purposes.

\section{Results and Discussion}

\section{The number of addition and the sources of the plant}

Based on 2008 to 2018 data, plants collection addition of CBG was experienced increased (Table 1). In totally, plants collection resulted from exploration were dominated as much as 248 specimens, donation 217 
specimens, self-propagation seven specimens, and one specimen from seeds exchange. The specimen is Acacia caffra (Leguminosae) that accepted from Johannesburg Botanic Garden, South Africa in 2002 and planted in 2014 (Registration Unit-CBG, 2018b). Because of the increasingly strict regulations in Indonesia about flora and fauna transfer materials, then this source would not be further explained.

Tabel 1. The additions of CBG's plants collection based on the sources of the acceptance from 2008 to 2018.

\begin{tabular}{ccccc}
\hline \multirow{2}{*}{ Year } & \multicolumn{4}{c}{ Sources of the plants acceptance } \\
\cline { 2 - 5 } & $\begin{array}{c}\text { Explo- } \\
\text { ration }\end{array}$ & $\begin{array}{c}\text { Dona- } \\
\text { tion }\end{array}$ & $\begin{array}{c}\text { Self } \\
\text { propagation }\end{array}$ & $\begin{array}{c}\text { Seed } \\
\text { exchange }\end{array}$ \\
\hline 2008 & 8 & 1 & 0 & 0 \\
2009 & 24 & 20 & 1 & 0 \\
2010 & 21 & 20 & 1 & 0 \\
2011 & 33 & 16 & 2 & 0 \\
2012 & 5 & 1 & 1 & 0 \\
2013 & 6 & 30 & 0 & 0 \\
2014 & 37 & 91 & 1 & 1 \\
2015 & 15 & 8 & 0 & 0 \\
2016 & 15 & 5 & 0 & 0 \\
2017 & 50 & 17 & 1 & 0 \\
2018 & 34 & 8 & 0 & 0 \\
Total & $\mathbf{2 4 8}$ & $\mathbf{2 1 7}$ & $\mathbf{7}$ & $\mathbf{1}$ \\
\hline
\end{tabular}

Plants collection in exploration activity was an act of taking plant materials both seedlings, cuttings or seeds of plant, from the original habitat, which would later be re-planted and breed at CBG. List of priority plants that would be collected from the field, previously conducted through literature study, inventory and recommendations from the nursery and registration unit of $\mathrm{CBG}$, consultation with the Research Center of Biology-LIPI, and the recommendations of the Ministry of Environment and Forestry. Nevertheless, it was possible to be done a plants collection outer of the list that meets the requirements of priority plants (e.g. unique or endangered, or had a high potential value of economic, ethno-botany, ornamental, development of the science, or other values).

Based on Figure 2, the addition of plants collection was significantly rising each year. The most addition was occured in 2014, with totally as much as 130 specimens (Registration Unit-CBG, 2018b). These planted plants were related to the number of availability of plants stock. The more plants stock are ready for planting, then the more of planting can be conducted.

More than $50 \%$ of enrichment in the last decade came from exploration effort. In each exploration trip, they can collect an average 300 to 400 of live plant specimens in the form of seedlings, seeds or cuttings. After maintenance and with an average survival rate above $60 \%$, each year CBG has sufficient plant stock in the framework of the collection enrichment, besides from other sources. Nevertheless, in 2014, 2015 and 2016 the contribution of exploration result has decreased in enriching the garden collection than a donation (Figure 2). This was due to the plants from the exploration from 2014 to 2016 still many in the maintenance phase, and not ready to be set as ready to be planted.

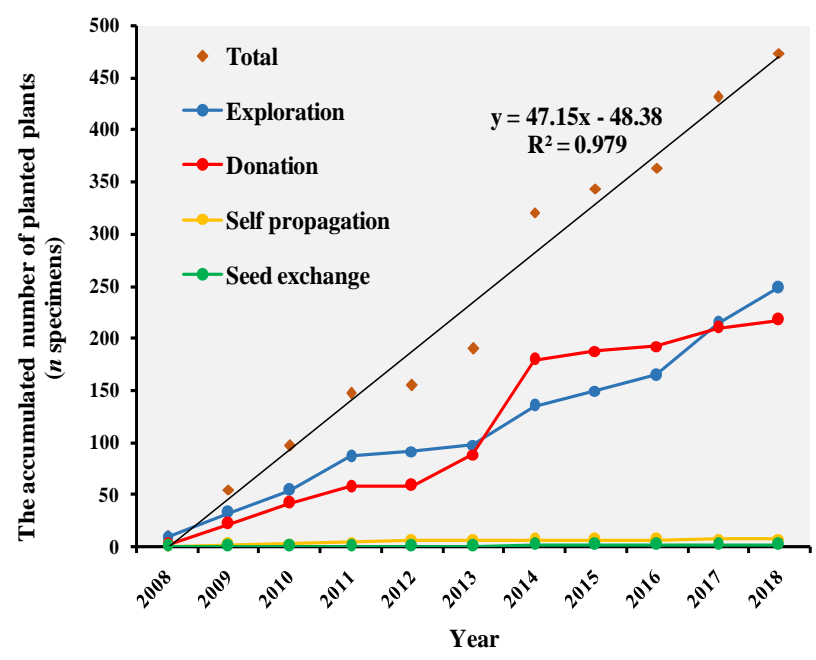

Figure 2. The trend of planted plants to be the garden collections at $\mathrm{CBG}$.

Based on source, plants from exploration originated from Sumatran mountains as much as 163 specimens and Javan mountains 62 specimens (Table 2). Plants from Sumatran mountains were dominated because since $2006 \mathrm{CBG}$ has routinely conducted exploration activities and plants collection, as part of exsitu conservation, with a focus on plants of the mountains in Sumatra.

Table 2. Originated plants from exploration effort.

\begin{tabular}{clc}
\hline No. & Area of exploration & $\begin{array}{c}\text { The number of plants } \\
(\boldsymbol{n} \text { - specimens })\end{array}$ \\
\hline 1. & Sumatra & 163 \\
2. & Java & 62 \\
3. & Papua & 11 \\
4. & Unidentified $\left.{ }^{*}\right)$ & 7 \\
5. & East Nusa Tenggara & 3 \\
6. & Sulawesi & 2 \\
\hline
\end{tabular}

Note: unidentified occurred because recorded data may only show the origin of "Indonesia" in general. Source: Registration Unit-CBG, 2018b. 
The activities were conducted once or twice a year depends on institution budget. These efforts were expected to help conserve threatened species in their natural habitat and as a part of ex-situ conservation (Richards et al., 2007). The few explorations location that conducted in Sumatra is mount Ledang, mount Sago Malintang, mount Singgalang, mount Marapi (West Sumatra), mount Dempo (South Sumatra), Mount Leuser National Park (Aceh), Kerinci Seblat National Park (Jambi), mount Patah (Bengkulu) and mount Tanggamus and mount Pesagi (Lampung). The Java exploration conducted in mount Slamet, mount Kemulan-Dieng (Central Java), Mount Salak Halimun National Park, Mount Gede Pangrango National Park, Mount Ciremai National Park (West Java). CBG has also conducted exploration in mount Pampunami, mount Kapit Atosambun, mount Simbiedip (Manokwari-Papua), mount Wanggameti (East Nusa Tenggara) and mount Rantemario (South Sulawesi).

After taking the plants from their natural habitat, the next phase is maintenance. The maintenance phase plays a very important role, as it provides ready-to-plant plant stock. Based on Bradi \& Well (2014), a good growth medium has four main functions, there are nutrients suppliers and roots medium, provides water and water catchment, provides air circulation for roots respiration, and for the medium of plants development. Hartmann et al. (2010), a good medium has several requirements, which are the ability to preserve humidity, good aeration and drainage, low salinity and clear from pests and diseases.

In the maintenance phase, each plant specimen was grown in different medium to adapt their natural habitat in the wild (Hartmann et al., 2010). Growth medium has previously given Furadan at a dose of 7.5 to $10 \mathrm{~g}$ per sack sized $40-50 \mathrm{~kg}$, in order to prevent disruption of worms and termites (Abd-El-Khair et al., 2019). Plants seedling and terrestrial orchids were grown in forest compost medium and paddy husks with a ratio of 1:1. Epiphyte orchids were grown by using growth medium in the form of chopped ferns, and Rhododendrons were grown in the growth medium of a mashed root of Kadaka (Haryati \& Siampa, 2018; Sari et al., 2018). Growth medium as maturate place of roots organ is an environmental factor which influences the seedling growth of plants.

The next source that enriches the collection was the donation. The donation can be originated from institution, corporation or private. Along 2008 to 2018, there were 217 specimens originated from donation. The number of local donation is 189 specimens and 28 specimens came from foreign donation. The foreign institutions that donate were Kunming Botanical Garden and Xishuangbanna Tropical Botanical Garden (China), Botanischer Garten der Universitat Tubingen and
Botanischer Garten der Martin-Luther-Deutschland (Germany), University of Athens (Greece).

The number of planted plants from foreign donation is described in Figure 3. Furthermore, the local institutions have also contributed the donation. They were Tahura Juanda (Bandung), Komatsu Project (P3HKA) - Department of Forestry (Bogor), Kuningan Botanic Garden (Kuningan), Hutan Adat Tau Taa Wana (Central Sulawesi), mount Halimun Salak National Park (Bogor), etc.

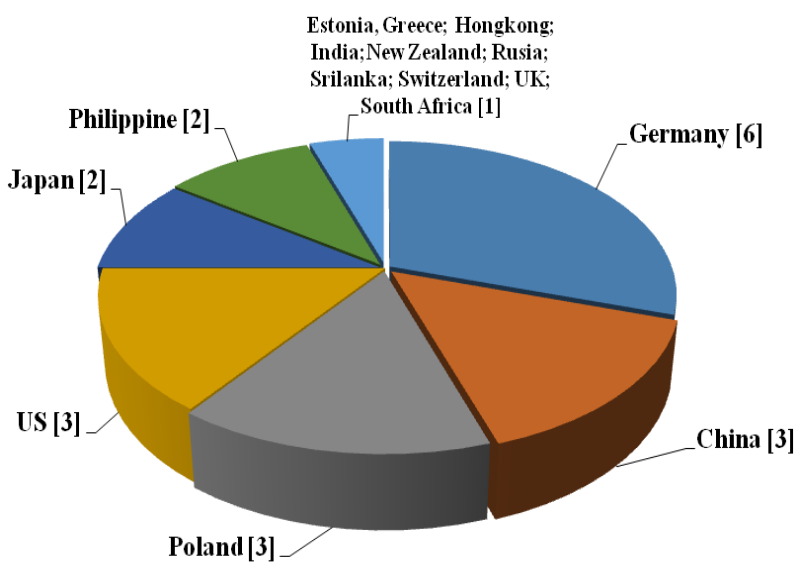

Figure 3. The donation from foreign institutions and the number of its planted plants.

Some corporations and privates, both foreign and local, have also contributed to donate some plants to CBG. Some of them are PT EISAI (Sukabumi), PT Kimia Farma (Bandung), Linggarjati Indah (Kuningan), PT Indo-Pacific (Jakarta), Mustika Ratu (Bogor), etc., and some researchers from local and foreign (the identity of private contributors were not displayed in order to keep the privacy).

Next, in order to develop the number of the garden plants, it also conducted self-propagation by staff of CBG. The seven plants that propagated (Table 1) because the number is limited. The details of the plants were described in Table 3.

Table 3. The plant species that self propagated by CBG's staff.

\begin{tabular}{lll}
\hline Year & \multicolumn{1}{c}{ Species } & \multicolumn{1}{c}{ Familia } \\
\hline 2009 & Allocasuarina paludosa & Casuarinaceae \\
2010 & Pilocarpus selloanus & Rutaceae \\
2011 & Cinchona calisaya & Rubiaceae \\
2011 & Xanthorrhoea presii & Xanthorrhoeaceae \\
2012 & Retrophyllum vitiense & Podocarpaceae \\
2014 & Enterolobium cyclocarpum & Leguminosae \\
2017 & Anigozanthos manglesii & Haemodoraceae \\
\hline
\end{tabular}


The diversity of the plants and the importance value to conservation

Furthermore, based on the data, species which planted as collection were dominated by the family of Nepenthaceae 84 specimens, Phyllantaceae 21 specimens, Lauraceae 15 specimens, Annonaceae and Leguminosae 14 specimens, Rosaceae and Rutaceae 12 specimens, Rubiaceae 11 specimens, Araliaceae and Malvaceae were 10 specimens (Figure 4a).

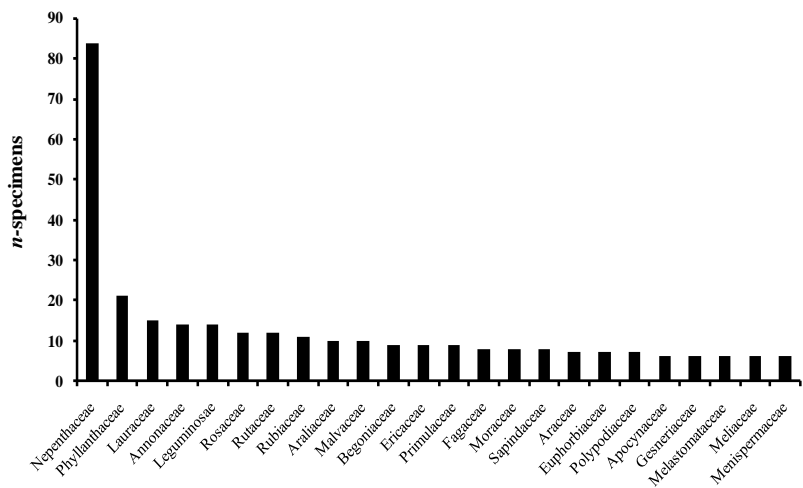

(a)

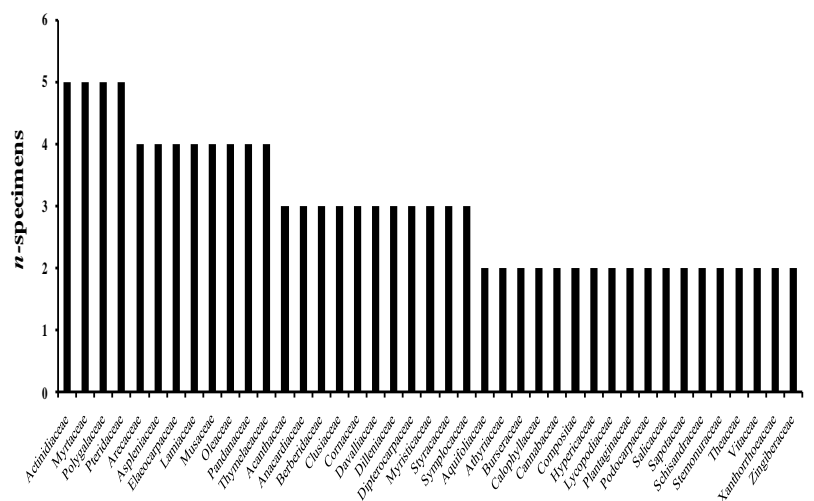

(b)

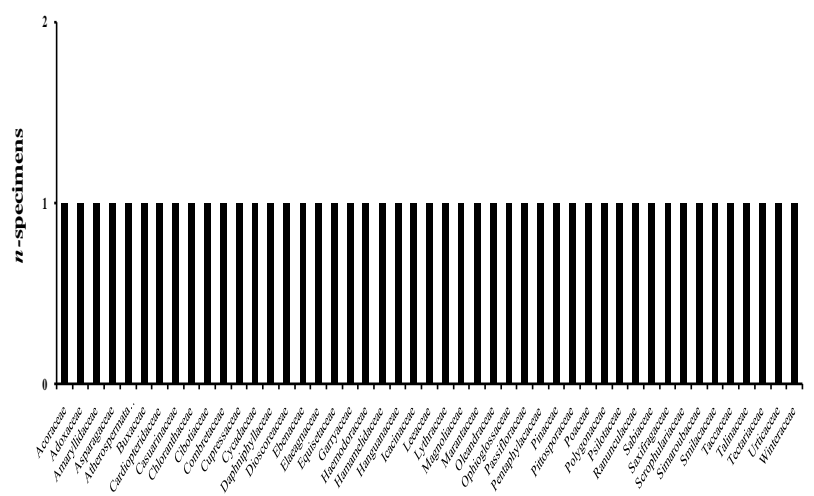

(c)

Figure 4. The number of planted plants based on familia: (a) the most planted to six specimens; (b) five to two specimens; (c) only one specimen.
Van Steenis (2006) claimed that some families such as Arecaceae, Araucariaceae, Clethraceae, Cunoniaceae, Ericaceae, Fagaceae, Lauraceae, Myrtaceae, Pentaphylaceae, Podocarpaceae, Symplocaceae and Theaceae were a better presence in medium and high elevation than in the lowlands. Each plant has an adaptation mechanism which enables to life adjacent to the surrounding environment. Environment parameters are determining ecological habitat in most of the plants. The interacted factors with a physiological mechanism of plants are temperature, lighting duration, wind, and humidity.

CBG with an altitude of approximately 1,200 to 1,425 meters above sea level and the number of wet months more than dry months, between seven to eight months per year (Widyatmoko et al., 2010), is a suitable location for the breeding of typical of tropical mountainous plants. In addition, besides typical plants of the tropical mountainous, planted specimens in CBG had also come from various species of lowland plants, such as the family of Dipterocarpaceae and Myristicaceae.

In a conservation term, it is important to use the justification restriction for traditional and also the conservation introductions. It needs a well understanding that some species have threats within their range that may cause extinction, therefore the existing reintroduction guidelines excuse conservation introductions only if there are no viable sites within a species range.

Based on the data, the most planted plants dominated by Nepenthes spp. (Figure 4). There were as much as 84 specimens of Nepenthes has planted at CBG in the last decade. Nepenthes has an importance value to conservation because over half of these carnivorous plant species assessed by the IUCN are listed as threatened (i.e., vulnerable, endangered, or critically endangered).

There presently are around 600 described species of these plants from 17 genera (Ellison \& Gotelli, 2009), with new species frequently being described (Cheek \& Jebb, 2009; Mann, 2007). There have been many studies regarding carnivorous plant conservation threats, and the threats as a group are also frequently represented (Schnell, 2002).

Of the 122 Nepenthes species that have been evaluated by the IUCN, ten are listed as critically endangered, 14 are listed as endangered, and 21 are listed as vulnerable (IUCN, 2019). Consequently, of these IUCN-evaluated species, $37 \%$ is considered a threatened. The threats to carnivorous plants have not formerly been quantified in any systematic method. These also often have complex interactions with animals aside from receiving nutrients from them For these threats, then $\mathrm{CBG}$ considers the need for immediate conservation efforts. The planted plants list and the conservation status of this species can be described in Table 4. 
Table 4. Species from Nepenthes spp. planted in CBG from 2008 to 2018.

\begin{tabular}{|c|c|c|c|}
\hline No. & Species & $\begin{array}{c}\text { The number } \\
\text { of plants } \\
\text { (n-specimens) }\end{array}$ & Conservation status $\left.{ }^{*}\right)$ \\
\hline 1. & Nepenthes maxima & 7 & $\mathrm{LC}$ \\
\hline 2. & Nepenthes rafflesiana & 4 & $\mathrm{LC}$ \\
\hline 3. & Nepenthes spathulata & 4 & $\mathrm{LC}$ \\
\hline 4. & Nepenthes tobaica & 4 & $\mathrm{LC}$ \\
\hline 5. & Nepenthes adnata & 3 & EN \\
\hline 6. & Nepenthes eustachys & 3 & No data and/ or unthreatened \\
\hline 7. & Nepenthes mirabilis & 3 & $\mathrm{LC}$ \\
\hline 8. & Nepenthes veitchii & 3 & $\mathrm{LC}$ \\
\hline 9. & $\begin{array}{l}\text { N. albomarginata, } N . \text { ampullaria, } N . \text { beccariana, } N . \\
\text { gracilis, } N . \text { gymnamphora, } N . \text { hirsuta, } N . \\
\text { jacquelineae, } N . \text { pectinata, } N . \text { stenophylla, } N . \\
\text { tomoriana, } N . \text { truncata }\end{array}$ & 2 & $\begin{array}{l}\text { Mostly LC (except } N . \text { beccariana and } N . \\
\text { jacquelineae are no data and/ or unthreatened); } \\
\text { EN (N. truncata) }\end{array}$ \\
\hline 10. & $\begin{array}{l}N . \text { alata, } N . \text { aristolochioides, } N . \text { bicalcarata, } N . \\
\text { clipeata, } N . \text { distillatoria, } N . \text { dubia, } N . \text { fusca, } N . \\
\text { glabratus, } N . \text { inermis, } N . \text { izumiae, } N . \text { jamban, } N . \\
\text { kerrii, } N . \text { khasiana, } N . \text { longifolia, } N . \text { lowii, } N . \\
\text { macfarlanei, } N . \text { merrilliana, } N . \text { murudensis, } N . \text { naga, } \\
N . \text { neoguineensis, } N . \text { northiana, } N . \text { petiolata, } N . \\
\text { ramispina, } N . \text { reinwardtiana, } N . \text { sanguinea, } N . \\
\text { singalana, } N . \text { smilesii, } N . \text { spectabilis, } N . \text { talangensis, } \\
N . \text { tentaculata, } N . \text { thorelii }\end{array}$ & 1 & $\begin{array}{l}\text { DD ( } N . \text { thorelii); } \\
\text { Mostly LC (except } N . \text { glabratus and } N . \text { jamban } \\
\text { are no data and/ or unthreatened); } \\
\text { VU (N. bicalcarata, } N . \text { distillatoria, } N . \text { lowii, } N \text {. } \\
\text { merrilliana, } N . \text { naga, } N . \text { northiana, } N . \\
\text { petiolata, } N . \text { ramispina, } N . \text { spectabilis }) ; \\
\text { EN ( } N . \text { khasiana, } N . \text { talangensis }) \text { to CR }(N . \\
\text { aristolochioides, } N . \text { clipeata, } N . \text { dubia })\end{array}$ \\
\hline
\end{tabular}

Note: $\left.{ }^{*}\right)$ IUCN conservation status [accessed: July 7th 2019], DD: Data Deficient; LC: Least Concern; NT: Near Threatened; VU: Vulnerable; EN: Endangered; CR: Critically Endangered.

Based on planted Nepenthes, of sixteen species (19 specimens) were included a threatened species (IUCN, 2019), with totally 50 species were planted (Table 4). N. aristolochioides, N. clipeata, and N. dubia are the most threatened with the status of "critically endangered" (IUCN, 2019). In order to minimize the possible damages and to maximize the maintenance, the collections were maintained in the greenhouse.

Beside Nepenthes spp., the importance value of the planted plants in CBG from 2008 to 2018 has come from diverse species. These species have not only enriched the garden collection but also has the important value to conservation. There are 71 different species included need to be conserved (Table 5). Of these species, there are 12 species being threatened in nature (IUCN, 2019).

Furthermore, Dipterocarpus cornutus (Dipt.), Hibiscus storckii (Malv.) and Psilotum nudum (Psil.) are the most threatened species with status "critically endangered" (CR). The secondly are Cycas riuminiana (Cycad.), Sequoia sempervirens (Cupr.), Shorea javanica and Shorea platyclados (Dipt.) with status "endangered" (EN). Next, Aquilaria filaria (Thym.), Horsfieldia glabra (Myrist.), Khaya anthotheca
(Meliac.), Macropanax concinnus (Aral.) and Saurauia lanceolata (Actin.) are also included threatened with status "vulnerable" (VU) (Table 5).

In general, the plant materials which taken from their natural habitat, especially from exploration effort, wherever possible has similar climatic and environmental conditions to their introduction site (Maschinski \& Albrecht, 2017), in this case, CBG. This recommendation is supported by studies that show plant community and habitat type matching of the source material to the re-introduction site is often more important than other factors (e.g., geographic distance) for long-term survival of rare plant reintroductions (Noel et.al., 2011).

Therefore, the selection and prioritization of threatened species of CBG for ex-situ management continue to be a serious challenge. These decisions are guided by a variety of criteria, including the level of threat; legislative and institutional responsibilities; the probability of successful storage and reintroduction; cost-effectiveness; relevant social, political, and economic issues; and curatorial preferences (Havens et al., 2006). 
Tabel 5. The diversity of the planted plants in CBG that has conservation value ${ }^{*}$, from 2008 to 2018 .

\begin{tabular}{|c|c|c|c|c|}
\hline No. & Species & Familia & $\begin{array}{c}\text { Conservation } \\
\text { status }\end{array}$ & $\begin{array}{c}\text { The number of } \\
\text { plants } \\
\text { (n-specimens) }\end{array}$ \\
\hline 1. & Cinnamomum heyneanum & Lauraceae & DD & 1 \\
\hline 2. & Pandanus tectorius & Pandanaceae & DD & 1 \\
\hline 3. & Acorus calamus & Acoraceae & $\mathrm{LC}$ & 1 \\
\hline 4. & Adinandra dumosa & Pentaphylacaceae & $\mathrm{LC}$ & 1 \\
\hline 5. & Aglaia tomentosa & Meliaceae & $\mathrm{LC}$ & 1 \\
\hline 6. & Aidia racemosa & Rubiaceae & $\mathrm{LC}$ & 1 \\
\hline 7. & Alangium javanicum & Cornaceae & $\mathrm{LC}$ & 1 \\
\hline 8. & Aleurites moluccanus & Euphorbiaceae & $\mathrm{LC}$ & 2 \\
\hline 9. & Antidesma bunius & Phyllanthaceae & $\mathrm{LC}$ & 1 \\
\hline 10. & Antidesma montanum & Phyllanthaceae & $\mathrm{LC}$ & 1 \\
\hline 11. & Aralia dasyphylla & Araliaceae & $\mathrm{LC}$ & 1 \\
\hline 12. & Cinchona calisaya & Rubiaceae & $\mathrm{LC}$ & 1 \\
\hline 13. & Cleistanthus oblongifolius & Phyllanthaceae & $\mathrm{LC}$ & 1 \\
\hline 14. & Coffea canephora & Rubiaceae & $\mathrm{LC}$ & 2 \\
\hline 15. & Cyathocalyx sumatranus & Annonaceae & $\mathrm{LC}$ & 1 \\
\hline 16. & Debregeasia longifolia & Urticaceae & $\mathrm{LC}$ & 1 \\
\hline 17. & Dillenia reticulata & Dilleniaceae & $\mathrm{LC}$ & 1 \\
\hline 18. & Diplazium esculentum & Athyriaceae & $\mathrm{LC}$ & 1 \\
\hline 19. & Elaeagnus conferta & Elaeagnaceae & $\mathrm{LC}$ & 1 \\
\hline 20. & Elaeocarpus petiolatus & Elaeocarpaceae & $\mathrm{LC}$ & 1 \\
\hline 21. & Enterolobium cyclocarpum & Leguminosae & $\mathrm{LC}$ & 1 \\
\hline 22. & Equisetum ramosissimum & Equisetaceae & $\mathrm{LC}$ & 1 \\
\hline 23. & Etlingera megalocheilos & Zingiberaceae & $\mathrm{LC}$ & 1 \\
\hline 24. & Ficus grossularioides & Moraceae & $\mathrm{LC}$ & 1 \\
\hline 25. & Ficus subulata & Moraceae & $\mathrm{LC}$ & 1 \\
\hline 26. & Garcinia burkillii & Clusiaceae & $\mathrm{LC}$ & 1 \\
\hline 27. & Garcinia dulcis & Clusiaceae & $\mathrm{LC}$ & 1 \\
\hline 28. & Guazuma ulmifolia & Malvaceae & $\mathrm{LC}$ & 1 \\
\hline 29. & Hanguana malayana & Hanguanaceae & $\mathrm{LC}$ & 1 \\
\hline 30. & Harpullia arborea & Sapindaceae & $\mathrm{LC}$ & 1 \\
\hline 31. & Ilex cymosa & Aquifoliaceae & $\mathrm{LC}$ & 1 \\
\hline 32. & Ilex micrococca & Aquifoliaceae & $\mathrm{LC}$ & 1 \\
\hline 33. & Macaranga tanarius & Euphorbiaceae & $\mathrm{LC}$ & 1 \\
\hline 34. & Maesa ramentacea & Primulaceae & $\mathrm{LC}$ & 1 \\
\hline 35. & Magnolia ovata & Magnoliaceae & $\mathrm{LC}$ & 1 \\
\hline 36. & Mallotus paniculatus & Euphorbiaceae & $\mathrm{LC}$ & 1 \\
\hline 37. & Mangifera foetida & Anacardiaceae & $\mathrm{LC}$ & 1 \\
\hline 38. & Maniltoa grandiflora & Leguminosae & $\mathrm{LC}$ & 1 \\
\hline 39. & Musa acuminata & Musaceae & $\mathrm{LC}$ & 1 \\
\hline 40. & Musa zebrina & Musaceae & $\mathrm{LC}$ & 1 \\
\hline 41. & Ophioglossum reticulatum & Ophioglossaceae & $\mathrm{LC}$ & 1 \\
\hline 42. & Osmanthus fragrans & Oleaceae & $\mathrm{LC}$ & 2 \\
\hline 43. & Photinia integrifolia & Rosaceae & LC & 1 \\
\hline
\end{tabular}




\begin{tabular}{|c|c|c|c|c|}
\hline 44. & Phyllocladus hypophyllus & Podocarpaceae & $\mathrm{LC}$ & 1 \\
\hline 45. & Pinus pinea & Pinaceae & $\mathrm{LC}$ & 1 \\
\hline 46. & Planchonella duclitan & Sapotaceae & $\mathrm{LC}$ & 1 \\
\hline 47. & Quercus pubescens & Fagaceae & $\mathrm{LC}$ & 1 \\
\hline 48. & Retrophyllum vitiense & Podocarpaceae & $\mathrm{LC}$ & 1 \\
\hline 49. & Sambucus nigra & Adoxaceae & $\mathrm{LC}$ & 1 \\
\hline 50. & Sandoricum koetjape & Meliaceae & $\mathrm{LC}$ & 1 \\
\hline 51. & Saurauia tristyla & Actinidiaceae & $\mathrm{LC}$ & 2 \\
\hline 52. & Schima wallichii & Theaceae & $\mathrm{LC}$ & 1 \\
\hline 53. & Sesbania sesban & Leguminosae & $\mathrm{LC}$ & 1 \\
\hline 54. & Sorbus corymbifera & Rosaceae & $\mathrm{LC}$ & 1 \\
\hline 55. & Tetradium daniellii & Rutaceae & $\mathrm{LC}$ & 1 \\
\hline 56. & Tipuana tipu & Leguminosae & $\mathrm{LC}$ & 1 \\
\hline 57. & Trevesia palmata & Araliaceae & $\mathrm{LC}$ & 1 \\
\hline 58. & Aglaia leptantha & Meliaceae & NT & 1 \\
\hline 59. & Aglaia silvestris & Meliaceae & NT & 1 \\
\hline 60. & Aquilaria filaria & Thymelaeaceae & VU & 1 \\
\hline 61. & Horsfieldia glabra & Myristicaceae & $\mathrm{VU}$ & 3 \\
\hline 62. & Khaya anthotheca & Meliaceae & VU & 1 \\
\hline 63. & Macropanax concinnus & Araliaceae & $\mathrm{VU}$ & 1 \\
\hline 64. & Saurauia lanceolata & Actinidiaceae & VU & 1 \\
\hline 65. & Cycas riuminiana & Cycadaceae & EN & 1 \\
\hline 66. & Sequoia sempervirens & Cupressaceae & $\mathrm{EN}$ & 1 \\
\hline 67. & Shorea javanica & Dipterocarpaceae & $\mathrm{EN}$ & 1 \\
\hline 68. & Shorea platyclados & Dipterocarpaceae & $\mathrm{EN}$ & 1 \\
\hline 69. & Dipterocarpus cornutus & Dipterocarpaceae & $\mathrm{CR}$ & 1 \\
\hline 70. & Hibiscus storckii & Malvaceae & $\mathrm{CR}$ & 1 \\
\hline 71. & Psilotum nudum & Psilotaceae & CR & 1 \\
\hline
\end{tabular}

Noted: The list arranged alphabetically of each category of conservation status and started from the lowest to the most threatened.

*) IUCN conservation status [accessed: July 7th 2019], DD: Data Deficient; LC: Least Concern; NT: Near Threatened; VU:

Vulnerable; EN: Endangered; CR: Critically Endangered.

Whenever possible, target species for ex-situ management should be identified before they experience catastrophic declines, because the chances of successful recovery and reintroduction can be severely reduced when sampling genetically depauperate populations (Maunder et al., 1999), and because sampling numerically small populations has a proportionally greater impact on population viability (Menges et al., 2004).

In order to maintain the survivorship, CBG conducted some efforts to alleviate the threats or eliminated prior to introduction. Nursery area at CBG is set into a desirable site which has biological and physical features (community composition, topography, soil type, microclimate, etc.) similar to those of plants. Plant conditions monitored daily by paying attention to the condition of planting media, fertilizing, watering and doing the pest and disease management, as well as the ability of the growth and development.
CBG as an ex-situ conservation area also conducts an edu-ecotourism effort. The plants were planted by following the taxa-relationship and considering the proportion design of the comfortable view. Although the advantages of the green space are intangible, however, the vegetation is of substantial value to providing the community with a social communal area. This emphasizes the existence of CBG as an important conservation area for the environment and surrounding communities.

Based on the addition, it was expected to provide the added value to the efforts of ex-situ plants conservation, and roles in the development of research and education. The collection addition is only a part of the conservation efforts conducted by CBG. Existing plants conservation efforts are not only limited to the enrichment, but also how CBGs can disseminate them to the wider community. This intended that the efforts are more leverage and able to generate public awareness. 


\section{Conclusions}

In the last decade, $\mathrm{CBG}$ has tended to increase the addition of plants collection of the garden. More than half of the addition acquired from exploration and plants collection that organized to help conserve threatened plant species. This effort is still continuously conducted by $\mathrm{CBG}$ as a part of ex-situ plants conservation. As much as $32.6 \%$ of preserved specimens have an important value to the plants conservation, and almost half of the specimens $(49.3 \%)$ were Nepenthes spp. and the rest are from Angiosperms. N. aristolochioides, $N$. clipeata, N. dubia (Nepenthes), and H. storckii and $P$. nudum (Angiosperms) are the most threatened species. These collection addition and the background efforts to achieve it were only half part of the conservation efforts conducted by CBG. The existing plant conservation efforts are not only limited to enrich the garden collection but also how CBGs can disseminate them at once to generate the awareness to the wider community.

\section{Acknowledgements}

Our grateful towards all staff of CBGs' Registration Unit, Didi Rasidi, Habibulloh, Puji Soepriati, Yudi Suhendri, and Agus Darmawan for cooperation in data compilation. This paper expected to be our small contribution in disseminating the information and knowledge about CBG towards the scientific community and the public.

\section{References}

Abd-El-Khair, H., El-Nagdi, W.M.A., Youssef, M.M.A., Abd-Elgawad, M.M.M. \& Dawood, M.G. (2019). Protective effect of Bacillus subtilis, B. pumilus, and Pseudomonas fluorescens isolates against root knot nematode Meloidogyne incognita on cowpea. Bulletin of the National Research Centre 43 (2019): 64. DOI: https://doi.org/10.1186/s422 $\underline{69-019-0108-8}$

[BGCI] Botanic Gardens Conservation International. (2012). International Agenda for Botanic Gardens in Conservation (2nd Ed.). Richmond. Botanic Gardens Conservation International, 48 pp. ISBN: 978-1-905164-45-5

Bradi, N.C. \& Well, R.R. (2014). Nature and Properties of Soils (14th Ed.). New Jersey. Pearson, 980 pp. ISBN: 978-0132279383

Braverman, I. (2014). Conservation without nature: the trouble with in situ versus ex situ conservation.
Geoforum 51: 47-57. DOI: https://doi.org/10.101 6/j.geoforum.2013.09.018

Broadhurst, L.M., Lowe, A., Coates, D.J., Cunningham, S.A., McDonald, M., Vesk, P.A. \& Yates, C. (2008). Seed supply for broadscale restoration: maximizing evolutionary potential. Evolutionary Applications 1 (4): 587-597. DOI: https://doi.org /10.1111/j.1752-4571.2008.00045.x

Brummer, E.C., Barber, W.T., Collier, S.M., Cox, T.S., Johnson, R., Murray, S.C., Olsen, R.T., Pratt, R.C. \& Thro, A.M. (2011). Plant breeding for harmony between agriculture and the environment. Frontiers in Ecology and the Environment 9 (10): 561-568. DOI: https://doi.org/10.1890/ 100225

Cheek, M. \& Jebb, M. (2009). Nepenthes group Montanae (Nepenthaceae) in Indo-China,with $N$. thai and N. bokor described as new. Kew Bulletin 64 (2): 319-325. Accessed from https://www. jstor.org/stable/20649658

Davis, K. (2008). A CBD manual for botanic gardens. Richmond. Botanic Gardens Conservation International, 36 pp. ISBN: 978-1-905164-29-5

Ellison, A.M. \& Gotelli, N.J. (2009). Energetics and the evolution of carnivorous plants -Darwin's 'most wonderful plants in the world'. Journal of Experimental Botany 60 (1): 19-42. DOI: https:// doi.org/10.1093/jxb/ern179

Goettsch, B., Hilton-Taylor, C., Cruz-Piñón, G., Duffy, J.P., Fances, A., Hernandez, H.M. \& Gaston, K.J. (2015). High proportion of cactus species threatened with extinction. Nature Plants 1 (2015): 15142. DOI: https://doi.org/10.1038/n plants. 2015.142

Hartmann, H.T., Kester, D.E., Davies Jr., F.T. \& Geneve, R.L. (2010). Hartmann \& Kester's Plant Propagation: Principles and Practices (8th Ed.). New Jersey. Pearson, 928 pp. ISBN: 978-0135 014493

Haryati, B.Z. \& Siampa, M. (2018). Respon Anggrek Hitam (Coelogyne pandurata) Hasil Perbanyakan Kultur Jaringan Terhadap Berbagai Media Tanam. AgroSainT UKI Toraja 9 (1): 25-30. Accessed from http://journals.ukitoraja.ac.id/in dex.php/agro/article/view/568/452 
Havens, K., Vitt, P., Maunder, M., Guerrant Jr., E.O. \& Dixon, K. (2006). Ex Situ Plant Conservation and Beyond. BioScience 56 (6): 525-531. DOI: https: //doi.org/10.1641/0006-3568(2006)56[525:ESPC $\mathrm{AB}] 2.0 . \mathrm{CO} ; 2$

Havens, K., Kramer, A.T. \& Guerrant Jr., E.O. (2014). Getting plant conservation right (or not): the case of the United States. International Journal of Plant Sciences 175 (1): 3-10. DOI: https://doi.org $\underline{/ 10.1086 / 674103}$

[IUCN] International Union for the Conservation of Nature. (2019). The IUCN Red List of Threathened Species. Accessed from: https:// www.iucnredlist.org/

Ketua Lembaga Ilmu Pengetahuan Indonesia. Surat Keputusan Ketua LIPI No. 23/Kep/D.5/87, tanggal 17 Januari 1987 tentang Organisasi dan Tata Kerja Lembaga Ilmu Pengetahuan Indonesia. Lembaga Ilmu Pengetahuan Indonesia. Jakarta.

Laumonier, Y., Uryu, Y., Stuwe, M., Budiman, A., Setiabudi, B. \& Hadian, O. (2010). Eco-floristic sectors and deforestation threats in Sumatra: identifying new conservation area network priorities for ecosystem-based land use planning. Biodiversity and Conservation 19 (4): 1153 1174. DOI: https://dx.doi.org/10.1007/s10531-01 0-9784-2

Mann, P. (2007). Drosera gibsonii (Droseraceae), a new pygmy Drosera from south-west western Australia. Nuytsia 16 (2): 321-323. Accessed from https://florabase.dpaw.wa.gov.au/nuytsia/ar $\underline{\text { ticle/466 }}$

Maschinski, J. \& Albrecht, M.A. (2017). Center for Plant Conservation's Best Practice Guidelines for the reintroduction of rare plants. Plant Diversity 39 (2017): 390-395. DOI: https://doi.org/10.1016/j. pld.2017.09.006

Maunder, M., Culham, A., Bordeu, A., Allanguillame, J. \& Wilkinson, M.J. (1999). Genetic diversity and pedigree for Sophora toromiro (Leguminosae): A tree extinct in the wild. Molecular Ecology 8 (5): 725-738. DOI: https://doi.org/10.1046/j.1365-29 4X.1999.00609.X

Menges, E.S., Guerrant Jr., E.O. \& Hamzé, S. (2004). Effects of seed collection on the extinction risk of perennial plants. In Guerrant Jr., E.O., Havens, K. \& Maunder, M. (Eds.), Ex Situ Plant Conser- vation: Supporting Species Survival in the Wild (pp: 305-324). Washington (DC). Island Press., 536 pp. ISBN: 9781559638753

Menteri Lingkungan Hidup dan Kehutanan RI. Peraturan Menteri Lingkungan Hidup dan Kehutanan Republik Indonesia Nomor P.106/MEN LHK/SETJEN/KUM.1/12/2018 tentang Jenis Tumbuhan dan Satwa yang Dilindungi. Berita Negara RI Tahun 2019 Nomor 32. Direktorat Jenderal Peraturan Perundang-Undangan Kementerian Hukum dan HAM RI. Jakarta.

Neale, D.B. \& Kremer, A. (2011). Forest tree genomics: growing resources and applications. Nature Reviews Genetics 12 (2): 111-122. DOI: https:// doi.org/10.1038/nrg2931

Noel, F., Prati, D., van Kleunen, M., Gygax, A., Moser, D. \& Fische, M. (2011). Establishment success of 25 rare wetland species introduced into restored habitats is best predicted by ecological distance to source habitats. Biological Conservation 144 (1): 602-609. DOI: https://doi.org/10.1016/j.biocon. $\underline{2010.11 .001}$

Presiden Republik Indonesia. Peraturan Pemerintah Republik Indonesia Nomor 7 Tahun 1999 tentang Pengawetan Jenis Tumbuhan dan Satwa. Lembaran Negara RI Tahun 1999 Nomor 14. Sekretariat Negara. Jakarta.

Registration Unit-CBG. (2018a). Monthly reports of plants collection richness of CBG of 2018. Cianjur. Cibodas Botanic Garden. [Indonesian] [Unpublished]

Registration Unit-CBG. (2018b). Annual reports of microclimates of CBG from 2012 to 2018: Form D10. Cianjur. Cibodas Botanic Garden. [Indonesian] [Unpublished]

Richards, C.M., Antolin, M.F., Reilley, A., Poole, J. \& Walters, C. (2007). Capturing genetic diversity of wild populations for ex-situ conservation: Texas wild rice (Zizania texana) as a model. Genetic Resource and Crop Evolution 54 (4): 837-848. DOI: https://doi.org/10.1007/s10722-006-9167-4

Sari, A.P., Listiawati, A. \& Anggorowati, D. (2018). Pengaruh Jenis Media Tanam Terhadap Pertumbuhan Anggrek Paphiopedilum hookerae pada Fase Remaja. Jurnal Sains Mahasiswa Pertanian 7 (3): 1-8. Accessed from http:// jurnal. untan.ac.id/index.php/jspp/article/view/26569 
Tanksley, S.D. \& Mccouch, S.R. (1997). Seed banks and molecular maps: Unlocking genetic potential from the wild. Science 277 (5329): 1063-1066. DOI: https://doi.org/10.1126/science.277.5329.10 $\underline{63}$

Widyatmoko, D., Suryana, N., Suhatman, A. \& Rustandi (Eds.). (2010). List of Living Plants Collection Cultivated in Cibodas Botanic Gardens. Cianjur. Cibodas Botanic Gardens, Indonesian Institute of Sciences, 131 pp. ISBN: 978-979-99448-5-6 van Steenis, C.G.G.J. (2006). The Mountain Flora of Java (2nd Ed.). Leiden. E.J. Brill, 240 pp. ISBN: 978-90-04-15347-9

Vitt, P., Havens, K., Kramer, A.T., Sollenberger, D. \& Yates, E. (2010). Assisted migration of plants: changes in latitudes, changes in attitudes. Biological Conservation 143 (1): 18-27. DOI: ht tps://doi.org/10.1016/j.biocon.2009.08.015 